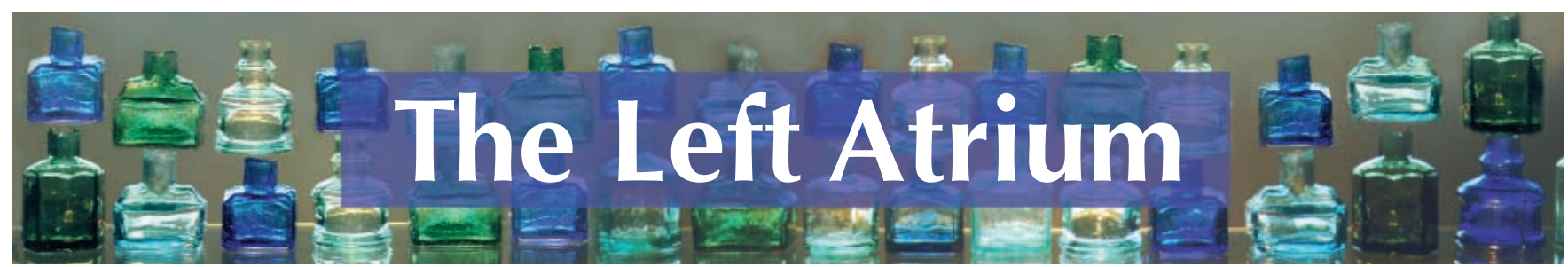

\section{A psychiatric reformation}

The cure of folly: a psychiatrist's cautionary tale

Gordon Warme

Toronto: ECW Press; 2003

378 pp $\$ 22.95$ (paper) ISBN 1-55022-571-5

$\mathrm{H}$ aving come to medicine via the study of religion, and to religion via Joseph Campbell's delightful and insightful writings on myth, I jumped at the opportunity to review this book by University of Toronto psychiatrist Gordon Warme. It was the title that drew me, I confess - or its resonance with another. In the early sixteenth century, at the dawn of what we now think of as the Reformation, one Erasmus of Rotterdam penned and published (ostensibly to entertain his peer Thomas More) In Praise of Folly, a satirical indictment of the theologians and churchmen (yes) of his day. Having now read Warme's book and found not a single reference to Erasmus, I am still convinced that the erudite psychiatrist had Erasmus' book (or at least its title) in mind when he wrote The Cure of Folly.

Erasmus was uncomfortable with what he perceived to be his church's folly, and Warme clearly is more than a little troubled by the dogma and practices of his own institution, modern psychiatry. Make no mistake: Warme speaks of faith no less than did Erasmus. Noting that he no longer publishes in psychiatric journals, Warme writes, "[t]he referees who screen such articles, more than anything else, have become censors and protectors of the faith. Anything that deviates from the faith is screened out - and ... I'm no longer a believer."

Where Erasmus sought to entertain Thomas More, and perhaps goad the church into change, his contemporary, Martin Luther, was less subtle. The polemical Luther nailed his complaints to the cathedral door and simply demanded reformation, refusing to re- cant. Similarly, Warme's writing has a certain exaggerated, demanding and, frankly, irritating tone; I am convinced that he intends to shock, and in one or two places his colloquialisms border on being offensive (call me a prude). He rails against " $[\mathrm{m}]$ odern psychiatric madmen [who] believe patients are polluted by abnormal chemicals," and has harsh words for "those who are currently hi-jacking, raping, and pillaging [his] noble profession." Of his colleagues who "want the safe, calming language of disease," Warme writes:

Cowardice drives them to invent a biological mythology propped up by fake research that always yields the same conclusions: most patients get better whatever the treatment. I tell my friends they should keep their fingers crossed for their patients; any officially approved action will work just fine. Their preoccupation with imaginary diseases helps them evade the psychological insights of people like Homer, Shakespeare or Thomas Mann. Like bloodletting, phrenology and the antidepressive regime, their methods will fade; Shakespeare will still be studied 500 years from now.

Now, this is not news. Nor is the rhetorical technique of creating caricatured "straw enemies" terribly useful. We might meet psychiatrists or other physicians whose references to Shakespearean themes become tiresome even as we long for relief from those whose focus on lab values would have us disregard our patients' humanity. The truth is, I think, that there will usually exist a degree of overlap, a greyness that blurs the distinction between Warme's villains and heroes.

But once we get past the hyperbole, we hear Warme at his most sincere: " $[\mathrm{H}] \mathrm{e}$ who thinks his psychiatrist is wiser than he, is an ordinary mortal, but he whose psychiatrist has not helped him to see the folly of that belief has been neglected." And so his caricatures are forgivable, especially given that he so obviously exaggerates his own gifts and flaws as well as those of his "enemies." For it is just these gifts and flaws, the belches and poetry that issue forth from earthbound humanity, that Warme would have us attend to.

Noting that "[good] shrinks are mythologizers," Warme suggests that all "psychiatric residents should read The Brothers Karamazov" and makes the claim that "the important things about people are poetic and imaginative ... poetic truth rather than boring rational truth." And, elsewhere: "Playwrights and novelists, if they've done their jobs, work on a plane beyond judgment," which is precisely where the good psychiatrist ought to locate his or her couch. Warme bemoans his "wrongheaded colleagues [who] are sure that people's lives are caused," and that all that is needed to effect cure is the identification and understanding and acceptance of causative factors. Implied if not explicit is the notion that what most psychiatrists want to do is to improve their patients, to make them better. And this, as Warme sees it, is heavily judgemental. For his part, regarding a particularly difficult patient, Warme writes, "I wish that Cathy had been spared her pain, but I never wanted her to be a different person." 
In many ways The Cure of Folly is autobiographical, at once the story of a loss of faith and the development of, or growing into, an arguably deeper faith informed by great literature and myth in ways that, at least in Warme's account, contemporary psychiatry generally is not. Thus the cleverness of the title: the book both traces the cure of Warme's own folly and describes his understanding of the predicament of modern psychiatry, which he feels has forgotten that "madness is just a variant on the weird behaviour of the rest of us." The "fraudulence of the psychiatric enterprise" as Warme would have us understand it, is its insistence on curing folly. "I won't pathologize my patients," he notes, "a boon when trying to understand another person's world, but awkward when the world of psychiatry asks me for diagnoses, wants me to 'normalize' patients, or eagerly try to change people."

Hubris, of course, lurks shallowly below the surface in all of us who presume to put our ideas in print, and I think Warme's editors might have been a trifle more strict with him in this regard. That said, this is a wonderful read. The literary references and epigraphs alone are worth the price of the book. A favourite, attributed to
Montaigne, opens the first chapter: "Man is quite insane. He wouldn't know how to create a maggot, and he creates gods by the dozen." But here is Warme, near the end of the book: "As far as I can see, any god worth his [sic] salt has a repertoire of weirdness at his disposal, as does every literary and mythological figure. It's what makes human conduct riveting."

\section{Ted St. Godard}

PGY1

Family Medical Centre

University of Manitoba

Winnipeg, Man.

\section{Room for a view}

\section{Solitude}

Tn April, Lenny Moscow paced at 1 night reciting arteries, nerves, and the Krebs cycle. He locked himself into his dorm room. He drank coffee and played jazz - Coltrane, Davis, Parker. "Lenny!" I whacked the wall. "Lenny, shut up! It's three a.m. I need sleep."

"Rubens?" He yelled into the wall. "Is that you?"

"I am sleeping, Lenny. Lower the volume."

"Rubens, I am cramming. Do you understand?"

For ten days in April, Moscow took cafeteria meals to his room. He studied morning to evening, slept three hours after supper, and stayed awake all night. His only intermezzo was a trip to the bathroom. His grey eyes, dark stubble and gaunt body gave him an anarchist look. "I have to study all first-year medicine. It's life and death, Rubens."

"Lenny," I asked, "why did you leave it so long?"

"I have a death wish."

A month earlier, Moscow had been living at his girlfriend Tanya's flat, writing poetry and spending the evenings at a pub debating Life, Art and Marx. Whenever I had a beer with him, he was witty and anxietyfree. No one realized he was a medical student. Lenny had disappeared from classes. He was against formal instruction. In February I had warned him. "Lenny, be careful. The profs know you skip class."

"So what? Is it a crime to discuss great ideas?"

"They will make an example of you."

"I will make an example of them," he said, jabbing me with his finger. "This is a free world."

I had the room next to Moscow in our dorm; we were good friends, but I rarely saw him. During second semester he sneaked into Tanya's Ibsen class and read Sartre in a café. He wrote for the university journal. He published poetry. "People say I don't belong," he told me. "It's untrue. I want to be a doctor as much as you - my problem is there's too much to know. There is little time. Death stops us."

"It would help if you attended class. People think you don't care."

"I don't care?" Moscow stormed. "Forgive my passion. My teachers are dull, the courses uninspiring. How can we be illiterate doctors? Why is there no Art in medicine?"

You either loved Lenny or you hated him. He argued that teachers were prigs, that the university was a bastion of conservatism. He ridiculed medicine, had long hair, agitated against Vietnam and drove draftdodgers to Canada. He was a firebrand. Classmates mocked him because he questioned everything. It didn't help that his girlfriend Tanya, an exchange student, was drop-dead gorgeous.

Lenny caressed her in public whenever possible.

I had a crush on Tanya. I hated Lenny. I loved Lenny. I wanted to be Lenny.

But he lived life too fast. I feared he would burn up, like a shooting star.

Friday we met draft-dodgers at the Watertown border and drove them to Kingston. They stayed in our dorm. Lenny had the contact; I was sworn to secrecy. One week before final exams, during a spring snowstorm, I picked up a Louisiana draft-dodger with his banjo, Fadeus Jacques. He slept in my room on a cot.

By this time Lenny was popping wake-ups around the clock and cramming nonstop.

"Heck," Fadeus said, "that Lennyboy does talk mighty fast."

We lay in the dark. Lenny recited cra- 